\title{
Identification of an immunodominant epitope in glycoproteins $B$ and $G$ of herpes simplex viruses (HSVs) using synthetic peptides as antigens in assay of antibodies to HSV in herpes simplex encephalitis patients
}

\author{
S. S. BHULLAR ${ }^{1}$, N. H. CHANDAK ${ }^{1}$, N. N. BAHETI ${ }^{1}$, H. J. PUROHIT ${ }^{2}$, G. M. TAORI ${ }^{1}$, \\ H. F. DAGINAWALA ${ }^{1}$, R. S. KASHYAP ${ }^{*}$
}

${ }^{1}$ Biochemistry Research Laboratory, Central India Institute of Medical Sciences, Nagpur - 440 010, India; ${ }^{2}$ Environmental Genomics Unit, National Environmental Engineering Research Institute, Nehru Marg, Nagpur - 440 020, India

Received January 27, 2014; accepted August 7, 2014

\begin{abstract}
Summary. - Herpes simplex encephalitis (HSE) is a severe viral infection of the central nervous system (CNS). Assay of antibody response is widely used in diagnostics of HSE. The aim of this study was to identify an immunodominant epitope determining the antibody response to herpes simplex viruses (HSVs) in cerebrospinal fluid (CSF) of HSE patients. The synthetic peptides that resembled type-common as well as type-specific domains of glycoproteins B (gB) and $\mathrm{G}(\mathrm{gG})$ of these viruses were evaluated for binding with IgM and $\operatorname{IgG}$ antibodies in CSF samples from HSE and non-HSE patients in ELISA. The QLHDLRF peptide, derived from $\mathrm{gB}$ of HSV was found to be an immunodominant epitope in the IgM and IgG antibody response. The patients with confirmed and suspected HSE showed in ELISA against this peptide $26 \%$ and $23 \%$ positivities for IgM, $43 \%$ and $37 \%$ positivities for IgG and $17 \%$ and $15 \%$ for both IgM and IgG antibodies, respectively. The total positivities of $86 \%$ and $75 \%$ for both IgM and IgG antibodies were obtained in the patients with confirmed and suspected HSE, respectively. These results demonstrate that a synthetic peptide-based diagnostics of HSE can be an efficient and easily accessible alternative. This is the first report describing the use of synthetic peptides derived from HSVs in diagnostics of HSE using patients' CSF samples.
\end{abstract}

Keywords: herpes simplex viruses; herpes simplex encephalitis; synthetic peptide; epitope; IgM antibody; IgG antibody

\section{Introduction}

Herpes simplex encephalitis (HSE) is a severe viral infection of the human central nervous system (CNS) and the most common cause of non-epidemic encephalitis contributing to $10-20 \%$ of viral encephalitis cases (Banatvala, 2011). There are no specific clinical symptoms in HSE that differ from other encephalities (Whitley et al., 1982; Kohl, 1988).

“Corresponding author: e-mail: raj_ciims@rediffmail.com; phone: +0712-2236441.

Abbreviations: $\mathrm{HSV}(\mathrm{s})=$ herpes simplex virus(es); HSE $=$ herpes simplex encephalitis; $\mathrm{CSF}$ = cerebrospinal fluid; $\mathrm{gB}$ = glycoprotein $\mathrm{B} ; \mathrm{gG}=$ glycoprotein $\mathrm{G}$
The current clinical and laboratory analysis for HSE diagnostics are based on medical history and examination followed by analysis of cerebrospinal fluid (CSF) for the identification of the infecting organism by viral cultivation, brain biopsy, PCR and serology. However, due to inherent limitations of these tests the diagnostics of HSE is always challenging.

Detection of herpes simplex virus (HSV) DNA in CSF by PCR is now recognized as the standard laboratory diagnostics (Puchhammer-Stöckl et al., 1990; Aurelius et al., 1991). Serological diagnostics has widely been adopted to determine antibody response in HSE (MacCallum et al., 1974; Koskiniemi and Vaheri, 1982). Several studies have reported that, PCR as well as detection of specific antibodies in sera and CSF samples should be retrospectively analyzed 
for the diagnosis of HSE, so as to understand pathogenesis and follow the course of the disease (Akçali et al., 2008).

The approach of peptide synthesis has advanced the use of synthetic peptides to study protein-protein interactions (Merrifield, 1963). Several immunodiagnostic tests for the detection of antibodies have been developed for the detection of viral, bacterial and parasitic diseases based on synthetic peptides derived from antigenic proteins (Gómara and Haro, 2007). To our knowledge not much has been reported regarding the use of envelope glycoprotein peptides of the herpes simplex virus 1 (HSV-1) and herpes simplex virus 2 (HSV-2) in analysis of HSE patients ' CSF by ELISA protocol. The aim of this study was to identify an immunodominant epitope determining the antibody response to HSV glycoprotein $\mathrm{B}(\mathrm{gB})$ and $\mathrm{G}(\mathrm{gG})$ in CSF of HSE patients. For this purpose synthetic peptides resembling type-common as well as type-specific domains of HSV gB and gG, respectively were prepared and tested in ELISA with IgM and IgG antibodies in CSF of HSE-confirmed patients, HSE-suspected patients and control subjects. In the ELISA the QLHDLRF peptide exhibited the highest positivities for the tested samples from HSE patients and consequently was identified as the immunodominant epitope of $\mathrm{HSV}$ gB/gG.

\section{Materials and Methods}

Study subjects. The study involves patients with suspicion of viral encephalitis based on symptoms viz., presence of fever, altered mental status (low level of consciousness, behavior or personality

Table 1. Synthetic peptides

\begin{tabular}{lll}
\hline Glycoprotein/HSV & Peptide & Sequence \\
\hline & P-2 & LPQSPGPAFPLAE \\
P-3 & NRPVVPS \\
gG/HSV-1 & P-4 & TPPTIIGPLA \\
& P-5 & MATHLCG \\
P-6 & THPSVRYVCLP \\
P-8 & HTPLFSFLTASPALDTLF \\
\hline & P-10 & QPRRCPT \\
& P-13 & DRAPVPFEEVID \\
P-14 & DHEFVPLEVYT \\
P-15 & DSGLLDYTE \\
P-16 & QLHDLRF \\
& P-17 & MKALYPLTT \\
P-18 & RYMALVS \\
& P-19 & LPRRVVRH \\
P-20 & SPKTCGSYTY \\
& P-22 & EGGPCVPPVPA \\
& P-23 & WRSVPPVWYSA \\
P-25 & P-26 & PDAPFPP \\
& &
\end{tabular}

changes) and other clinical manifestations (e.g. focal neurological deficits, seizures), CSF findings showing mild increase in protein, glucose often normal and mild pleocytosis. Diagnostics performed in the first week of hospitalization included staining for bacterial culture, determination of the protein, sugar level and cell counts in CSF, computed tomography scan and magnetic resonance imaging of the brain. The 40 control subjects used in the study had other CNS infections (bacterial, fungal etc.) and non-infectious neurological disorders (hypertension, epilepsy, stroke etc.). The samples of viral encephalitis patients were further grouped into 35 confirmed HSE (PCR positive) and 105 suspected HSE cases (based on clinical symptoms). The study has been carried out at Central India Institute of Medical Sciences, Nagpur, India, and was ethically approved.

Synthetic peptides. The sequences of envelope glycoproteins (structural proteins) $\mathrm{gB}$ and $\mathrm{gG}$ of different strains of HSV were retrieved from EXPASY proteomic server-UniProtKB/Swiss-Prot. Strains which were used to obtain gB sequence from HSV-1 were strain 17: P10211; strain F: P06436; strain Patton: P08665; strain KOS: P06437 and from HSV-2 were strain 333: P06763; strain HG52: P08666; strain SA8: P24994. The consensus sequence of gB of HSV-1 and HSV-2 was obtained by multiple sequence alignment by CLC sequence viewer (version 6.6.2). The gG sequences were obtained from strain 17: P06484 of HSV-1 and strain HG52: P13290 of HSV-2. The antigenic peptides were identified from the consensus sequence of $\mathrm{gB}$ and from sequences of HSV-1 and HSV-2 gG on the basis of online software which uses Kolaskar and Tongaonkar method (Kolaskar and Tongaonkar, 1990). Peptides were designed with varying antigenicity. The sequence homology of peptides was checked with other organisms using NCBI BLAST. Both type-common and type-specific peptides were selected (Table 1). Peptides were custom synthesized from Hongkong GenicBio BioTech Co., limited with 95\% purity and quantity of $10 \mathrm{mg}$ each with no modification and were finally dissolved in concentration of $1 \mathrm{mg} / \mathrm{ml}$ of PBS.

ELISA. Hundred microlitres of $5 \mathrm{ng} / \mu \mathrm{l}$ of different peptides were coated in microtiter wells and incubated for $3 \mathrm{hr}$ at $37^{\circ} \mathrm{C}$. The wells were then blocked with $0.5 \%$ BSA after washing once and kept for 2 hr at $37^{\circ} \mathrm{C}$. The wells were washed and stored at $4^{\circ} \mathrm{C}$ overnight. Next day, diluted CSF (1:5 in PBS) samples were added to the wells and incubated for $1 \mathrm{hr}$ at $37^{\circ} \mathrm{C}$. After washing the wells with PBS, $100 \mu \mathrm{l}$ of secondary antibody (goat-anti-human IgM/IgG-HRP conjugated antibody, 1:10,000, 1:5,000 respectively) was added and incubated for $45 \mathrm{~min}$ at $37^{\circ} \mathrm{C} .100 \mu \mathrm{l}$ of $3,3^{\prime}, 5,5^{\prime}$-tetramethylbenzidine $/ \mathrm{H}_{2} \mathrm{O}_{2}$ substrate solution was then added and incubated for $10 \mathrm{~min}$. Color development reaction was stopped by adding $100 \mu \mathrm{l}$ of $2.5 \mathrm{~N} \mathrm{H}_{2} \mathrm{SO}_{4}$. The results were read at $\mathrm{A}_{450}$.

Real-time PCR. Total DNA was extracted from $200 \mu$ of CSF samples from patients by using a ZR viral DNA kit (Zymo Research, USA), according to the manufacturer's protocol. The amplification reactions were carried out using SYBR green and the primers for HSV which were described earlier (Bhullar et al., 2013). The cycle threshold (Ct) was calculated as the cycle number at which the 
concentration increase became exponential. The specific target amplification was analyzed by melt curve analysis of the StepOne real-time PCR system (Applied Biosystems, USA).

Statistical analysis. The cut off values for IgM and IgG were determined using the ROC analysis. In t-test, differences with $\mathrm{P} \leq 0.05$ were considered significant. All the statistical analyses were done with the help of MedCalc software (version 10.1.2).

\section{Results}

The IgM and IgG antibodies to $\mathrm{gB}$ and $\mathrm{gG}$ of $\mathrm{HSV}$ in CSF of HSE patients were detected by using synthetic peptides in ELISA. Table 2 and 3 show the mean value of absorbance for the binding of synthetic peptides to IgM and IgG antibodies in CSF from the HSV-infected (confirmed HSE)

Table 2. ELISA values for the binding of synthetic peptides to IgM antibodies

\begin{tabular}{|c|c|c|c|c|}
\hline \multirow{2}{*}{ Peptide } & \multicolumn{2}{|c|}{ Mean \pm SD } & \multirow{2}{*}{ P-value } & \multirow{2}{*}{ Cut-off value } \\
\hline & Confirmed HSE $(\mathrm{n}=35)$ & Control $(n=40)$ & & \\
\hline P-10 & $0.35 \pm 0.18$ & $0.30 \pm 0.08$ & $\mathrm{P}=0.1718$ & $>0.408$ \\
\hline P-13 & $0.32 \pm 0.15$ & $0.30 \pm 0.08$ & $\mathrm{P}=0.4148$ & $>0.37$ \\
\hline P-14 & $0.31 \pm 0.15$ & $0.26 \pm 0.11$ & $\mathrm{P}=0.0897$ & $>0.355$ \\
\hline P-15 & $0.31 \pm 0.14$ & $0.31 \pm 0.07$ & $\mathrm{P}=0.8179$ & $>0.398$ \\
\hline P-16 & $0.34 \pm 0.12$ & $0.25 \pm 0.05$ & $\mathrm{P}=0.0001$ & $>0.322$ \\
\hline P-17 & $0.34 \pm 0.20$ & $0.30 \pm 0.08$ & $\mathrm{P}=0.2535$ & $>0.398$ \\
\hline P-18 & $0.35 \pm 0.17$ & $0.29 \pm 0.13$ & $\mathrm{P}=0.1686$ & $>0.478$ \\
\hline P-2 & $0.31 \pm 0.14$ & $0.28 \pm 0.11$ & $\mathrm{P}=0.3119$ & $>0.316$ \\
\hline P-3 & $0.29 \pm 0.12$ & $0.30 \pm 0.15$ & $\mathrm{P}=0.7601$ & $>0.319$ \\
\hline P-4 & $0.30 \pm 0.13$ & $0.28 \pm 0.12$ & $\mathrm{P}=0.5005$ & $>0.345$ \\
\hline P-5 & $0.29 \pm 0.12$ & $0.27 \pm 0.14$ & $\mathrm{P}=0.5235$ & $>0.293$ \\
\hline P-6 & $0.29 \pm 0.12$ & $0.26 \pm 0.13$ & $\mathrm{P}=0.3176$ & $>0.305$ \\
\hline P-8 & $0.28 \pm 0.11$ & $0.24 \pm 0.10$ & $\mathrm{P}=0.1112$ & $>0.292$ \\
\hline P-19 & $0.33 \pm 0.18$ & $0.30 \pm 0.19$ & $\mathrm{P}=0.4979$ & $>0.417$ \\
\hline P-20 & $0.30 \pm 0.12$ & $0.28 \pm 0.11$ & $\mathrm{P}=0.4640$ & $>0.333$ \\
\hline P-22 & $0.28 \pm 0.11$ & $0.27 \pm 0.12$ & $\mathrm{P}=0.7166$ & $>0.307$ \\
\hline P-23 & $0.29 \pm 0.11$ & $0.31 \pm 0.17$ & $\mathrm{P}=0.5667$ & $>0.294$ \\
\hline P-25 & $0.36 \pm 0.17$ & $0.33 \pm 0.16$ & $\mathrm{P}=0.4445$ & $>0.384$ \\
\hline P-26 & $0.34 \pm 0.17$ & $0.28 \pm 0.14$ & $\mathrm{P}=0.1049$ & $>0.401$ \\
\hline
\end{tabular}

Table 3. ELISA values for the binding of synthetic peptides to IgG antibodies

\begin{tabular}{|c|c|c|c|c|}
\hline \multirow{2}{*}{ Peptide } & \multicolumn{2}{|c|}{ Mean \pm SD } & \multirow{2}{*}{ P-value } & \multirow{2}{*}{ Cut-off value } \\
\hline & Confirmed HSE $(n=35)$ & Control $(n=40)$ & & \\
\hline P-10 & $0.40 \pm 0.23$ & $0.36 \pm 0.13$ & $\mathrm{P}=0.3778$ & $>0.487$ \\
\hline P-13 & $0.38 \pm 0.19$ & $0.36 \pm 0.13$ & $\mathrm{P}=0.5984$ & $>0.47$ \\
\hline P-14 & $0.37 \pm 0.21$ & $0.31 \pm 0.12$ & $\mathrm{P}=0.1352$ & $>0.454$ \\
\hline P-15 & $0.39 \pm 0.21$ & $0.36 \pm 0.13$ & $\mathrm{P}=0.3778$ & $>0.487$ \\
\hline P-16 & $0.44 \pm 0.18$ & $0.32 \pm 0.11$ & $\mathrm{P}=0.0012$ & $>0.42$ \\
\hline P-17 & $0.37 \pm 0.23$ & $0.31 \pm 0.13$ & $\mathrm{P}=0.1748$ & $>0.459$ \\
\hline P-18 & $0.36 \pm 0.21$ & $0.30 \pm 0.17$ & $\mathrm{P}=0.1706$ & $>0.546$ \\
\hline P-2 & $0.43 \pm 0.12$ & $0.39 \pm 0.21$ & $\mathrm{P}=0.3410$ & $>0.488$ \\
\hline P-3 & $0.39 \pm 0.14$ & $0.34 \pm 0.17$ & $\mathrm{P}=0.1848$ & $>0.438$ \\
\hline P-4 & $0.40 \pm 0.14$ & $0.36 \pm 0.21$ & $\mathrm{P}=0.3582$ & $>0.476$ \\
\hline P-5 & $0.40 \pm 0.14$ & $0.39 \pm 0.20$ & $\mathrm{P}=0.8113$ & $>0.464$ \\
\hline P-6 & $0.39 \pm 0.12$ & $0.36 \pm 0.20$ & $\mathrm{P}=0.4575$ & $>0.446$ \\
\hline P-8 & $0.45 \pm 0.18$ & $0.40 \pm 0.31$ & $\mathrm{P}=0.4212$ & $>0.521$ \\
\hline P-19 & $0.39 \pm 0.13$ & $0.33 \pm 0.19$ & $\mathrm{P}=0.1323$ & $>0.45$ \\
\hline P-20 & $0.39 \pm 0.14$ & $0.37 \pm 0.18$ & $\mathrm{P}=0.6076$ & $>0.476$ \\
\hline P-22 & $0.37 \pm 0.12$ & $0.35 \pm 0.18$ & $\mathrm{P}=0.5912$ & $>0.433$ \\
\hline P-23 & $0.38 \pm 0.12$ & $0.34 \pm 0.18$ & $\mathrm{P}=0.2843$ & $>0.403$ \\
\hline P-25 & $0.42 \pm 0.09$ & $0.37 \pm 0.17$ & $\mathrm{P}=0.1375$ & $>0.48$ \\
\hline P-26 & $0.41 \pm 0.09$ & $0.36 \pm 0.15$ & $\mathrm{P}=0.1013$ & $>0.48$ \\
\hline
\end{tabular}


Table 4. Positivity for IgM and IgG antibodies detectable by the peptide P-16 in ELISA in patients with confirmed and suspected HSE and control subjects

\begin{tabular}{lllll}
\hline Subjects & IgM+/IgG- & IgG+/IgM- & IgM+/IgG+ & Total positivity \\
\hline Confirmed HSE $(\mathrm{n}=35)$ & $09(25.71 \%)$ & $15(42.85 \%)$ & $06(17.14 \%)$ & $30(85.71 \%)$ \\
\hline Suspected HSE $(\mathrm{n}=105)$ & $24(22.85 \%)$ & $39(37.14 \%)$ & $16(15.23 \%)$ & $79(75.23 \%)$ \\
\hline Control $(\mathrm{n}=40)$ & $1(2.5 \%)$ & $2(5 \%)$ & 0 & $3(7.5 \%)$ \\
\hline
\end{tabular}

and non-HSV infected groups (control group) as determined by indirect ELISA method. The mean absorbance value for both IgM and IgG antibodies detectable by P-16 in confirmed HSE group was found to be significantly elevated as compared to control group. No significant difference was obtained for the mean absorbance values of confirmed HSE in comparison to control group for peptides of $\mathrm{gG}$ of both HSV-1 and HSV-2.

Table 4 shows the occurrence of IgM and IgG antibodies detectable by P-16 in confirmed HSE, suspected HSE and

Table 5. Detection of HSV and IgM/IgG antibodies by the peptide P-16 in ELISA in patients on various days after admission

\begin{tabular}{|c|c|c|c|c|}
\hline $\begin{array}{l}\text { Patient } \\
\text { No. }\end{array}$ & $\begin{array}{l}\text { Sample } \\
\text { collection } \\
\text { interval } \\
\text { (days) }\end{array}$ & HSV & IgM antibodies & IgG antibodies \\
\hline \multirow{2}{*}{1} & 1 & Positive & Negative & Negative \\
\hline & 7 & Negative & Positive & Positive \\
\hline \multirow{2}{*}{2} & 1 & Positive & Positive & Positive \\
\hline & 7 & Negative & Negative & Positive \\
\hline \multirow{2}{*}{3} & 1 & Positive & Positive & Positive \\
\hline & 7 & Negative & Positive & Positive \\
\hline \multirow{2}{*}{4} & 1 & Positive & Negative & Negative \\
\hline & 7 & Positive & Negative & Negative \\
\hline \multirow{2}{*}{5} & 1 & Negative & Positive & Negative \\
\hline & 7 & Positive & Negative & Positive \\
\hline \multirow{2}{*}{6} & 1 & Positive & Positive & Positive \\
\hline & 14 & Negative & Negative & Positive \\
\hline \multirow{2}{*}{7} & 1 & Positive & Positive & Negative \\
\hline & 14 & Negative & Negative & Positive \\
\hline \multirow{2}{*}{8} & 1 & Positive & Negative & Negative \\
\hline & 14 & Negative & Negative & Positive \\
\hline \multirow{3}{*}{9} & 1 & Positive & Positive & Positive \\
\hline & 7 & Positive & Positive & Positive \\
\hline & 14 & Negative & Negative & Positive \\
\hline \multirow{3}{*}{10} & 1 & Positive & Positive & Negative \\
\hline & 7 & Positive & Positive & Positive \\
\hline & 14 & Negative & Negative & Positive \\
\hline \multirow{3}{*}{11} & 1 & Positive & Positive & Positive \\
\hline & 14 & Positive & Negative & Positive \\
\hline & 21 & Negative & Negative & Positive \\
\hline \multirow{3}{*}{12} & 1 & Positive & Positive & Positive \\
\hline & 14 & Positive & Negative & Positive \\
\hline & 21 & Negative & Negative & Positive \\
\hline
\end{tabular}

control group as determined from the cut-off value of $>0.322$ and $>0.42$ for IgM and IgG estimation in CSF samples of HSE patients. The positivity for IgM antibodies detectable by P-16 was highest in confirmed HSE group (25.71\%), whereas it was $22.85 \%$ in suspected HSE and $2.5 \%$ in control group. $42.85 \%, 37.14 \%$ and $5 \%$ of the cases of confirmed HSE, suspected HSE and control group respectively, were positive for IgG antibodies detectable by P-16. Considering the presence of both classes of antibodies together, $17.14 \%$ cases of confirmed HSE and $15.23 \%$ of the suspected HSE group were positive, whereas control group cases showed the absence of both the antibodies detectable by P-16. The combined positivity showed highest percentage of $85.71 \%$ in confirmed HSE and $75.23 \%$ in suspected HSE group for the determination of IgM and IgG antibodies detectable by P-16 in HSV infected patients.

Follow up CSF specimens were also obtained for $12 \mathrm{pa}-$ tients on day 1, 7, 14, and 21 of admission and the positivity and negativity of PCR, IgM and IgG antibodies detectable by P-16 were determined as shown in Table 5 . The IgM or IgG antibodies in initial or follow up CSF were detectable in all except one case. The IgM antibodies detectable by P-16 were obtained on day 1 and 7 but not on day 14 and 21 of admission. The IgG antibodies detectable by P-16 were obtained in CSF up to day 21 of admission. In one case, PCR of the CSF was negative, whereas the IgM antibodies were detectable by P- 16 .

\section{Discussion}

HSV is among the widespread viruses known to cause acute HSE in humans. The early diagnosis of HSE is difficult as the clinical picture of encephalitis caused by HSV is similar to that of other viral infections (Bhullar et al., 2011). PCR is although recognized as the standard laboratory technique for HSE diagnosis, however, it remains negative in cases where CSF has been obtained at late times following onset of illness or when the viral load is low in CSF. CSF antibody measurements may be useful in retrospective diagnosis in such cases. Therefore, analysis of IgM and IgG response in CSF may be a useful alternative tool for diagnosis of HSE. Detection of herpes virus-specific antibodies permits diagnosis of an infection when virologic methods such as cultivation, antigen detection, and PCR are impractical, too costly, or yield negative results. 
HSV-1 infections elicit strong antibody responses to the HSV-2 and vice versa due to high sequence homology between the two viruses (McClung et al., 1976; Eberle and Courtney, 1981). The type common antibody response against HSV is mostly attributed to $\mathrm{gB}$, a 904-aa protein and a major component of infected cell membranes and virion envelopes (Vestergaard, 1980; Cai et al., 1988). Although the aa similarity between HSV-1 and HSV-2 is high, the envelope gG, a 238-aa long chemokine-binding protein, is the only HSV antigen known to induce type-specific antibody responses and is therefore used in serological assays to discriminate between HSV-1 and HSV-2 infections (Ashley, 1998; Görander et al., 2003). These glycoprotein sequences were selected to obtain peptides with antigenic epitopes on the basis of prediction analysis by Kolaskar and Tongaonkar method.

A total of 12 peptides consisting 6 peptides each of HSV-1 and HSV-2 gG were synthesized and analyzed in cases of confirmed HSE and control groups. Studies have been reported describing the possibility of HSV serology by using synthetic peptides of gG (Levi et al., 1996). Immunodominant typespecific epitopes for human antibodies have been identified and should be useful for type-specific serodiagnosis of HSV-1 and HSV-2 (Grabowska et al., 1999; Kasubi et al., 2005). However, in this study, the selected peptides of gG region were not found to be immunodominant epitopes for the diagnosis of HSE. There are studies supporting these findings which state the limits in reliability of gG based type-specific serologic assays for HSV-1 and HSV-2 due to the high rates of seroreversion, defined as the change in an individual's antibody status from positive to negative over time, suggesting that their use in HSV acquisitional studies would not be useful (Schmid et al., 1999; Cherpes et al., 2003).

The ideal peptide-based seroassay should combine high sensitivity and specificity and should be based on a wellconserved HSV antigen evoking a strong antibody response against antigenic determinants (Bergström and Trybala, 1996). The sequence of $g B$ is well known to be conserved in HSV. Out of 7 peptides selected for type-common sequences of HSV-1 and HSV-2 gB, the absorbance values of only one peptide (P-16) of $\mathrm{gB}$ region showed significant difference for antibody analysis in CSF of confirmed HSE and control group. Almost $86 \%$ of the confirmed HSE cases were found to be positive for the presence of IgM and/or IgG antibodies using this peptide. There is only one reported study available which determines immunity induced by peptides corresponding to the antigenic sites of gB (Mester et al., 1990). It is reported that antibodies in CSF against $\mathrm{gB}$ in HSV were detected earlier than antibodies to the other viral proteins, probably because of high immunogenicity of gB (Kahlon et al., 1987). One study demonstrated that $\mathrm{gB}$ is presented with the same kinetics as a classical early-gene product and it is the possibility that $\mathrm{gB}$ could be an effective target as HSV emerges from latent infection (Mueller et al., 2003). It has also been shown that the functional domains of gB involved in cell penetration and cell fusion, and the major antigenic domains are highly conserved in peripheral and CNS HSV isolates (Sivadon et al., 1998) therefore, variation in antibody response against this protein could be least suspected.

The P-16 was further used for the determination of antibodies in PCR negative cases but suspected for HSE on the basis of clinical and other laboratory analyses. In our study, out of 105 PCR negative cases, approximately 75\% of the cases were positive for IgM or IgG antibodies detectable by P-16. Failure of the PCR in HSE patients where intrathecal antibody response is obtained has been reported (Puchhammer-Stöckl et al., 2001; Fomsgaard et al., 1998). Therefore, antibody detection using P-16 can be pursued in cases where there is high suspicion of HSV infection of the CNS and PCR of the CSF was negative.

In addition to that, approximately $14 \%$ of PCR positive cases were not found to be positive for the presence of any of the antibodies detectable by the particular peptide. To rule out the possibilities, the IgM and IgG antibodies were detected in follow up CSF samples of 12 patients from whom the CSF was obtained on day 1, 7, 14 and 21 of admission. The IgM antibodies detectable by P-16 were obtained on day 1 and 7 of admission, however it was not found on day 14 and 21. The IgG antibodies detectable by P-16 were obtained in CSF on day 7, 14 and 21 of admission. All the 12 cases were PCR positive in CSF collected at day 1 except one case where the IgM antibodies were detectable by P-16. Thus, in cases where CSF shows negativity for HSV DNA, the IgM or IgG antibodies could be detected. This finding could be helpful in improved diagnostics of the disease and early administration of antiviral therapy. There were some cases in which the first CSF of follow up samples showed negativity for antibodies. The CSF samples of patients had been collected in between 4 to 12 days after the onset of illness in patients. Previous study explains why the sensitivity of this method is time dependent. One study has reported similar specificity in early and late samples, but an increased sensitivity up to $90.5 \%$ if the samples were collected more than 1 week after the onset of symptoms (Sauerbrei and Wutzler, 2002).

There are very few Indian publications for determining the incidence of HSE in India (Satishchandra et al., 1993; Gambhir et al., 1999). There are only two Indian studies that determined the serological profile of patients with HSE (Ratho et al., 1999; Panagariya et al., 2001). As far as we know, this is the first report describing the use of synthetic peptide of HSV for serological diagnosis in HSE patients. We conclude that this synthetic gB peptide with sequence QLHDLRF may be useful for detecting IgM or IgG antibodies in CSF of HSE patients. The peptide based ELISA is specific and sensitive as compared to detection of the virus by PCR. The method is inexpensive and reliable. 
Acknowledgements. Dr. H. N. Madhavan, President, Vision Research Foundation, Sankara Nethralaya, Chennai, India is gratefully acknowledged for providing HSV-1 and HSV-2 DNA as a kind gift. This study is a part of in-house project of Central India Institute of Medical Sciences, Nagpur.

\section{References}

Akçali A, Ozkaya E, Yilmaz D, Uyar Y, Oncül O (2008): Investigation of herpes simplex virus in viral meningoencephalitis suspected cases using molecular and serological methods. Mikrobiyol. Bul. 42, 421-428.

Ashley RL (1998): Genital herpes: Type-specific antibodies for diagnosis and management. Dermatol. Clin. 16, 789-793. http://dx.doi.org/10.1016/S0733-8635(05)70048-6

Aurelius E, Johansson B, Sköldenberg B, Staland A, Forsgren M (1991): Rapid diagnosis of herpes simplex encephalitis by nested polymerase chain reaction assay of cerebrospinal fluid. Lancet 337, 189-192. http://dx.doi. org/10.1016/0140-6736(91)92155-U

Banatvala JE (2011): Herpes simplex encephalitis. The Lancet Infectious Diseases 11, 80-81. http://dx.doi.org/10.1016/ $\underline{\mathrm{S} 1473-3099(11) 70012-3}$

Bergström T, Trybala E (1996): Antigenic differences between HSV-1 and HSV-2 glycoproteins and their importance for type-specific serology. Intervirology 39, 176-184.

Bhullar SS, Chandak NH, Purohit HJ, Taori GM, Daginawala HF, Kashyap RS (2013): Determination of viral load by quantitative real-time PCR in herpes simplex encephalitis patients. Intervirology $57,1-7$. http://dx.doi. org/10.1159/000351521

Bhullar SS, Kashyap RS, Chandak NH, Purohit HJ, Taori GM, Daginawala HF (2011): Protein A-based ELISA: its evaluation in the diagnosis of herpes simplex encephalitis. Viral Immunol. 24, 341-346. http://dx.doi.org/10.1089/ vim.2010.0129

Cai WH, Gu B, Person S (1988): Role of glycoprotein B of herpes simplex virus type 1 in viral entry and cell fusion. J. Virol. 62, 2596-2604.

Cherpes TL, Ashley RL, Meyn LA, Hillier SL (2003): Longitudinal reliability of focus glycoprotein G-based type-specific enzyme immunoassays for detection of herpes simplex virus types 1 and 2 in women. J. Clin. Microbiol. 41, 671-674. http://dx.doi.org/10.1128/JCM.41.2.671-674.2003

Eberle R, Courtney RJ (1981): Assay of type-specific and typecommon antibodies to herpes simplex virus types 1 and 2 in human sera. Infect. Immun. 31, 1062-1070.

Fomsgaard A, Kirkby N, Jensen IP, Vestergaard BF (1998): Routine diagnosis of herpes simplex virus (HSV) encephalitis by an internal DNA controlled HSV PCR and an IgG-capture assay for intrathecal synthesis of HSV antibodies. Clin. Diagn. Virol. 9, 45-56. http://dx.doi.org/10.1016/S09280197(97)10006-X

Gambhir IS, Singh NN, Singh DS, Gulati AK (1999): Herpes simplex virus-1 encephalitis in eastern Uttar Pradesh. J. Assoc. Physicians India 47, 1149-1151.
Gómara MJ, Haro I (2007): Synthetic peptides for the immunodiagnosis of human diseases. Curr. Med. Chem. 14, 531-546. http://dx.doi.org/10.2174/092986707780059698

Görander S, Svennerholm B, Liljeqvist JA (2003): Secreted portion of glycoprotein $\mathrm{g}$ of herpes simplex virus type 2 is a novel antigen for type-discriminating serology. J. Clin. Microbiol. 41, 3681-3686. http://dx.doi.org/10.1128/ JCM.41.8.3681-3686.2003

Grabowska A, Jameson C, Laing P, Jeansson S, Sjögren-Jansson E, Taylor J, Cunningham A, Irving WL (1999): Identification of type-specific domains within glycoprotein $\mathrm{G}$ of herpes simplex virus type 2 (HSV-2) recognized by the majority of patients infected with HSV-2, but not by those infected with HSV-1. J. Gen. Virol. 80, 1789-198.

Kahlon J, Chatterjee S, Lakeman FD, Lee F, Nahmias AJ, Whitley RJ (1987): Detection of antibodies to herpes simplex virus in the cerebrospinal fluid of patients with herpes simplex encephalitis. J. Infect. Dis. 155, 38-44. http:// dx.doi.org/10.1093/infdis/155.1.38

Kasubi MJ, Nilsen A, Marsden HS, Bergström T, Langeland N, Haarr L (2005): A branched, synthetic oligopeptide corresponding to a region of glycoprotein G of HSV-1 reacts sensitively and specifically with HSV-1 antibodies in an ELISA. J. Virol. Methods 125, 137-143. http://dx.doi. org/10.1016/j.jviromet.2005.01.006

Kohl S (1988): Herpes simplex virus encephalitis in children. Pediatr. Clin. North Am. 35, 465-483.

Kolaskar AS, Tongaonkar PC (1990): A semi-empirical method for prediction of antigenic determinants on protein antigens. FEBS Lett. 276, 172-174. http://dx.doi.org/10.1016/00145793(90)80535-Q

Koskiniemi ML, Vaheri A (1982): Diagnostic value of cerebrospinal fluid antibodies in herpes simplex virus encephalitis. J. Neurol. Neurosurg. Psychiatry 45, 239-242. http://dx.doi. org/10.1136/jnnp.45.3.239

Levi M, Rudén U, Wahren B (1996): Peptide sequences of glycoprotein G-2 discriminate between herpes simplex virus type 2 (HSV-2) and HSV-1 antibodies. Clin. Diagn. Lab. Immunol. 3, 265-9.

MacCallum FO, Chinn IJ, Gostling JV (1974): Antibodies to herpessimplex virus in the cerebrospinal fluid of patients with herpetic encephalitis. J. Med. Microbiol. 7, 325-331. http://dx.doi.org/10.1099/00222615-7-3-325

McClung H, Seth P, Rawls WE (1976): Relative concentrations in human sera of antibodies to cross-reacting and specific antigens of Herpes simplex virus types 1 and 2. Am. J. Epidemiol. 104, 192-201.

Merrifield RB (1963): Solid Phase Peptide Synthesis. I. The Synthesis of a Tetrapeptide. J. Am. Chem. Soc. 85, 2149-2154. http://dx.doi.org/10.1021/ja00897a025

Mester JC, Highlander SL, Osmand AP, Glorioso JC, Rouse BT (1990): Herpes simplex virus type 1-specific immunity induced by peptides corresponding to an antigenic site of glycoprotein B. J. Virol. 64, 5277-5283.

Mueller SN, Jones CM, Chen W, Kawaoka Y, Castrucci MR, Heath WR, Carbone FR (2003): The early expression of glycoprotein $\mathrm{B}$ from herpes simplex virus can be detected by 
antigen-specific CD8+ T cells. J. Virol. 77, 2445-2451. http://dx.doi.org/10.1128/JVI.77.4.2445-2451.2003

Panagariya A, Jain RS, Gupta S, Garg A, Sureka RK, Mathur V (2001): Herpes simplex encephalitis in North West India. Neurol. India 49, 360-365.

Puchhammer-Stöckl E, Presterl E, Crö̈ C, Aberle S, Popow-Kraupp T, Kundi M, Hofmann H, Wenninger U, Gödl I (2001): Screening for possible failure of herpes simplex virus PCR in cerebrospinal fluid for the diagnosis of herpes simplex encephalitis. J. Med. Virol. 64, 531-536. http:// dx.doi.org/10.1002/jmv.1082

Puchhammer-Stöckl E, Popow-Kraupp T, Heinz, FX, Mandl CW, Kunz C (1990): Establishment of PCR for the early diagnosis of herpes simplex encephalitis. J. Med. Virol. 32, 77-82. http://dx.doi.org/10.1002/jmv.1890320202

Ratho RK, Sethi S, Singh S (1999): Role of serology in the diagnosis of herpes simplex encephalitis. Indian J. Pathol. Microbiol. 42, 333-337.

Satishchandra P, Nandini M, Shankar SK, Vasudevarao T, Ravi V, Shenoy PK, Chatterjee S, Jain S (1993): Herpes simplex encephalitis: a diagnostic and therapeutic reapprisal. J. Assoc. Physicians India 41, 277-278.
Sauerbrei A, Wutzler P (2002): Laboratory diagnosis of central nervous system infections caused by herpesviruses. J. Clin. Virol. 25, S45-51. http://dx.doi.org/10.1016/S13866532(02)00033-1

Schmid DS, Brown DR, Nisenbaum R, Burke RL, Alexander D, Ashley R, Pellett PE, Reeves WC (1999): Limits in reliability of glycoprotein G-based type-specific serologic assays for herpes simplex virus types 1 and 2. J. Clin. Microbiol. 37, 376-379.

Sivadon V, Lebon P, Rozenberg F (1998): Variations of HSV-1 glycoprotein B in human herpes simplex encephalitis. J. Neurovirol. 4, 106-114. http://dx.doi. org/10.3109/13550289809113488

Vestergaard BF (1980): Herpes simplex virus antigens and antibodies: a survey of studies based on quantitative immunoelectrophoresis. Rev. Infect. Dis. 2, 899-913. http:// dx.doi.org/10.1093/clinids/2.6.899

Whitley RS et al. (1982): Herpes simplex encephalitis: Clinical Assessment. JAMA 247, 317-320. http://dx.doi. org/10.1001/jama.1982.03320280037026 